\title{
The Influence of Modern Education System in the Selection of a Higher Education Institution
}

\author{
Erika S. HUSZÁRIK, Kamilla SÁNTA and Patrik BAŠA* \\ 1 J. Selye University, Komarno, Slovakia, huszarike@ujs.sk; s.kamilla315@gmail.com; patrik.basa111@gmail.com \\ * Corresponding author: patrik.basa111@gmail.com
}

\begin{abstract}
Education plays a central role in society in terms of well-being in life, and can also be defined as an engine of economic development. The timeliness of our topic is given by the fact that one of the most important human factors in 21st century society is knowledge. The main goal of our research is to provide an insight into the relevant influencing factors that arise when a student selects a higher education institution. Furthermore, our goal is to provide a comprehensive picture of the most important motivational factors of high school and grammar school graduates that arise in them before choosing a higher education institution. The primary data collection of our research took the form of a direct mail questionnaire, during which we examined the intentions of high school and grammar school graduates to continue their education, as well as the influencing factors that play an important role in their lives in terms of further education. Based on our results, we have created an order of preference and a stepwise representation, which helps higher education institutions to increase the motivation of prospective students and to develop an appropriate education system.
\end{abstract}

Keywords: motivation; higher education system; selection; key factors

JEL Classification: I20; I21; I23

\section{Introduction}

For all countries, education is paramount in order to develop and prosper. Education shapes people's character and intelligence. It also provides a sense of motivation for everyone. The traditional education system at the tertiary level is a system where the student receives a systematic education at the university by taking "full-time" / part-time required courses. However, this type of system also has several disadvantages. Many developments can be expected in the period ahead, one of the foundations of which is the ongoing health crisis. One of the most likely developments in the next generation education system is online education, which is still being tried variously around the world today. Based on these, it can be said that online education has made rapid progress in recent years and at the same time has become one of the most debated subjects in the field of education. It has removed some of the main barriers to classroom education, such as location, accessibility, or just travel costs. Technological and pedagogical innovation has made the training system more backward. This experimental and choice-based education system is currently enjoyed by students at primary, secondary and tertiary levels. The use of a self-learning model through audio and video information is becoming increasingly popular and easier to apply among students. 
Higher education has the potential to provide different forms of distance learning, for example through TV channels, online education portals, in order to encourage the emerging generation to continue to develop.

The Choice-Based Credit System (CBCS) is a significant step forward in the model of education because it provides an opportunity to personalize learning in higher education. Such-based programs allow students to progress at their own pace, incorporate the process of prior learning assessment, and provide a logical framework for developing knowledge, skills, and experience to the value set by the institution. The CBCS helps students gain handson experience that is translated into academic credits. The system also works well for adults who return to school after a few years of work experience in order to complete their studies. This competency-based system requires better planning of courses than is currently the case with the traditional credit-based system. The competency-based system requires that all students be provided with hundreds of opportunities to understand the subject. The difficulties and limitations of the CBCS model prepare and support students at different rates due to their different abilities, in contrast to current classroom instruction. Competency models recognize the value of experiential learning in which students can develop and hone their skills. It is important to highlight that the logic of the competency-based credit system is compelling through individual, online, and traditional classroom learning. With regard to the online education system, it can be said that it is an advantage for students to have access to educational services anywhere, anytime, which features significantly save valuable time for students. The main benefits of online mobile education include prevalence, personalization, reduced costs, flexibility, increased convenience, and time savings. The competency-based credit system represents a significant improvement in the educational model by designing a new assessment system. It also provides an opportunity to personalize learning in higher education by providing appropriate guidance in the selection and assessment of subjects. The current driving force in the CBCS is to provide lower-cost educational opportunities through higher education institutions through flexible programs (Aithal \& Aithal, 2016).

\subsection{Overview of the Higher Education System}

Qualifications in Europe are comparable through the European Qualifications Framework. Most study programs include lectures and seminars, and assessment is done through essays and exams. Work in industry as well as the development of related projects are part of several study programs.

The main European training structures are:

- Bachelor's degree - Most full-time bachelor courses in Europe last 3 or 4 years. The first step is to complete a high school education. This is variable, so the admission requirements for the chosen study program must be checked in each case. This training is a great way to acquire the most significant skills and knowledge that will help you advance in your career. 
- Master's degree - Most full-time masters courses in Europe last 1 or 2 years. A master's degree is required to complete a bachelor's degree. A master's degree is a great way for a student to gain deeper or additional skills and knowledge that will help them advance their careers. It is especially helpful in gaining professional status.

- Doctoral/PhD training - Most full-time doctoral programs last 3 or 4 years. Bachelor's and master's degrees are also required to obtain a doctoral degree. The doctoral degree is ideal for those who are passionate about research. They are especially useful if the student wants to work at the university and also aims to become an expert in a particular field. Doctoral degrees usually involve a lot of independent study and research specializing in a topic. The student only needs to attend a few lecture and seminar, mostly doing independent research under the guidance of their supervisor. The purpose of a doctoral degree is to generate new information and ideas or to conduct original research to help advance a topic. It is also the student's responsibility to prepare for their doctoral dissertation during the study program.

In addition to the three main levels of study listed, students can complete many other higher education qualifications. The higher education system offers a wide range of study programs across Europe. Students can study astrophysics, biotechnology, energy management, history, information technology, international relations, languages, law, medicine, sociology, economics and much more. Most higher education study programs have a "modular" structure. This means that students can create a personalized study program by selecting several different modules or study units each year. There are thousands of universities, research institutes and higher education institutions in Europe (European Commission, 2017).

In the vast majority of countries, the introduction of the European Credit Transfer and Accumulation System (ECTS) was based on different legislation. Such legal frameworks are now in place in almost all countries. Each country and institution is currently focusing on the actual implementation and maintenance of the ECTS system. There is a need to support and encourage institutions so that the ECTS system can be properly embedded and implemented on the basis of learning outcomes and student workload (European Commission, 2009).

A university is a higher education institution that is entitled to at least 8 bachelor's and 6 master's degrees, or provides doctoral training, thus giving it the opportunity to award a doctoral degree. The University of Applied Sciences is a higher education institution with at least 4 bachelor's and 2 master's degrees and at least 2 dual courses in the field of engineering, informatics, agriculture, science or economics (Eurydice, online).

An article in the Portfolio published in 2020 shows that in Hungary, about 110,000 diplomas were issued by higher education institutions without language exams. Tamás Schanda stated that the government decided in the spring to temporarily abolish the previously prescribed requirements because the current health crisis threatens not only people's health, but also the economy and livelihood. Thanks to this change, young people will be in a better position in the labor market, as they will also have the opportunity to apply for job opportunities that they will not have before receiving their degree. The first step in 
the economic protection plan was that students who passed the final exam by 31 August 2020 could receive their degree even in the absence of a language exam. These measures apply to all forms of training except doctoral training. The opportunity was also available to students who would have had to take even more language exams to graduate (Portfolio, 2020).

Table 1 clearly shows that the number of live births showed a steadily declining trend between 1992 and 2001. Based on these, it can be stated that the number of students applying to a higher education institution results in a decrease due to this.

Table 1. Changes in the number of births in Hungary between 1992-2001 (Hungarian Central Statistical Office, 2020)

\begin{tabular}{|c|c|c|c|c|c|}
\hline Year & $\begin{array}{c}\text { The population, January } \\
\text { 1.given in thousands of } \\
\text { people }\end{array}$ & $\begin{array}{c}\text { Average, } \\
\text { January 1. }\end{array}$ & Live birth & Mortality & $\begin{array}{c}\text { natural } \\
\text { increase, } \\
\text { depopulation (-) }\end{array}$ \\
\cline { 2 - 6 } & Altogether & Altogether & Altogether & Altogether \\
\hline 1992 & 10374 & 37.5 & 121724 & 148781 & -27057 \\
\hline 1993 & 10365 & 37.6 & 117033 & 150244 & -33211 \\
\hline 1994 & 10350 & 37.7 & 115598 & 146889 & -31291 \\
\hline 1995 & 10337 & 37.8 & 112054 & 145431 & -33377 \\
\hline 1996 & 10321 & 38 & 105272 & 143130 & -37858 \\
\hline 1997 & 10301 & 38.1 & 100350 & 139434 & -39084 \\
\hline 1998 & 10280 & 38.3 & 97301 & 140870 & -43569 \\
\hline 1999 & 10253 & 38.5 & 94645 & 143210 & -48565 \\
\hline 2000 & 10222 & 38.7 & 97597 & 135601 & -38004 \\
\hline 2001 & 10200 & 39.2 & 97047 & 132183 & -35136 \\
\hline
\end{tabular}

\subsection{Key Motivational Competencies When Selecting a Higher Education Institution}

The need for further learning can be inserted into several steps of Maslow's pyramid. In the course of further studies, students acquire a profession and a qualification, which is a basic requirement for employment in the labor market, which results safety, permanence and housing for them. The university community, the professionals, satisfy the need to belong somewhere. If we examine the higher level needs, we can conclude that the desire for recognition and prestige can be achieved by obtaining a degree. The self-realization at the top of the Pyramid of Maslow can be interpreted in this respect as meaning that students choose a major that suits their interests in order to satisfy their academic interest (Hofmeister \& Tóth, 2006).

According to Rámháp (2017), Hungarian young people can be divided into several groups based on their attitudes towards further learning, which are as follows:

- Prestige-oriented - Individuals who want to acquire outstanding knowledge, have serious career plans, good educator, performance and a reputable institution are important to them.

- Experience seekers - Students for whom the completion of minimum conditions is important, in addition a good community, a good atmosphere and student programs can be 
included here. They are primarily looking for an institution where the conditions are relatively easier to meet and also feel good.

- Considered - The third group includes students whose decisions about further study are primarily determined by comfort, a favorable price, and a favorable future job. Value for money is important to them.

According to Rámháp, these groups should be taken into account, for example, during segmentation, as well as in the development of supply, the creation of a university image, and the creation of an appropriate communication strategy (Rámháp, 2017).

Students' motivation is also greatly influenced by external factors. These factors can be grouped into effects (based on rational consideration) as well as impacts of social environment and culture (behind which it is not necessary to find rational consideration). Decisions based on rational judgment include labor market opportunities, place in the social hierarchy, direct monetary expenditure and benefits, expected risk, legal constraints, system opportunities, information / orientation, and guidance systems (Halász, 2001; Belas et al., 2019).

Institutional choice models have been known in the literature since 1980. Csuka and Banász (2014) classify the models describing the election process into three groups.

- $\quad$ Economic models - They are based on maximizing utility and risk reduction is typical for young students. As a critique of the model can be stated that in all cases a rational decision and a complete supply of information are assumed.

- Sociological models - For this model, the emphasis is on social status as well as individual factors. Family and social background and education come to the fore. Parents education is also a significant influencing factor. It has been criticized that the decision is placed solely on the socio-sociological aspect.

- $\quad$ Mixed models - It is a combination of the two models listed previously, which manifests itself as assuming a rational decision but in turn taking into account the influential role of social background (Csuka \& Banász, 2014).

Institutional selection aspects can be approached from the perspective of student factors as well as institutional factors. In the case of the former, the opinion of social and economic status, parents' education, budget, financial support, career, parents, friends, teachers are authoritative. From an institutional point of view, geographical location, size, type of training, reputation, ranking and quality of education are important aspects. In addition, the infrastructure and equipment of the institution is an important influencing factor (Rámháp, 2017).

What opportunities do universities have today to encourage students to choose a higher education institution?

This is well illustrated by the so-called enrollment marketing model found in Kuráth's (2007) doctoral dissertation. The system includes external, and internal factors. Let's see exactly what they can be: 
- External influencing factors - characteristics of the city, availability of main institutions, unique nature of institutions, number of competitors, financing methods, demographic environment, lifestyle

- Internal influencing factors - feefficiency of admission information, admission requirements, marketing, quality of education, new trainings, training scale, favorable reimbursement, condition of classrooms, infrastructure, research opportunities, career opportunities, modern education organization

In addition, this includes, for example, additional services such as a library, an IT network, a study department, various mobility programs, or even scholarship opportunities. Students can also be attracted by the cultural opportunities offered by the university (sports facilities, accommodation, or even dining options). Among the enrollment marketing activities, university "open days" can be highlighted, where students have the opportunity to tour the campus as well as gather information at various booths. Other options include the annual Education Exhibition (Kuráth, 2007).

The decision-making process for further education in a higher education institution can be divided into three stages: the first phase, during which the student is willing to continue his / her studies at the university or college, the second phase, during which he / she starts visiting the university / colleges, and the third phase, when students choose the higher education institution to which they will apply. The student's socio-economic status, test scores, and study average (GPA) all play a role in the selection of the institution. However, students tend to update their educational expectations based on changes in academic information (Jackson, 2015).

Information on the use of students 'learning strategies can be extremely useful in achieving multiple goals. From the perspective of educators, it can be said that they are thus able to develop interventions designed to encourage learners to use useful learning strategies based on this type of information. In addition, students can use the information to better understand their general learning approaches. Finally, education becomes evaluable, for example, by adjusting the level of educational control, cooperative learning, and the use of educational technology. Research on the learning strategies employed by students is essential for planning optimal education (Meijs et al., 2019).

We found an extremely interesting study on the topic, which is related to the dissertation of Kéri (2015) for the National Scientific Student Conference. In her research, she specifically examines the motivations of foreign students to study in Hungary. The work shows that the students come to Hungary mostly because they had a specific goal and high expectations, and an important factor is that the Hungarian degree is accepted within the European Union. It is interesting and extremely instructive that the subjects of the research agreed the least that they would like to find a job in Hungary after graduating. In our view, this could be one of the most important factors that should be changed. Perhaps, if we get an answer on how to encourage students to continue their studies, it is conceivable that we will also get an answer on how to encourage them to settle in Hungary. To do this, however, we need to understand their motivations. In her hypothesis study, Kéri (2015) concluded that students 
are most motivated to learn about new cultures, learn languages (in this case, they refer specifically to English), and gain new experiences. This is a good starting point for learning their motivation. Extrinsic motivational factors also include the fact that a lot of students come with their acquaintances and a lot of people are influenced by the information and experience they hear from acquaintances, friends and relatives about the university. Intrinsic motivation clearly includes the acquisition of new knowledge as well as language learning opportunities. We believe that by "strengthening" these, we can make a major contribution to increasing students 'motivation (Kéri, 2015).

\section{Methodology}

The main goal of our research is to provide an insight into the influencing factor of modern education systems in the selection of a higher education institution. In our study, we examine modern education systems as well as the operation of the higher education system. Following this, we place great emphasis on the motivational factors of students that play a key role in the selection of a higher education institution. Considering the practical part of our research, our goal is to provide a comprehensive picture of these motivational factors in relation to Hungary. As a last step, the authors formulate the main conclusions and suggestions on the topic. The aim of the research in this problem area is to provide a comprehensive picture of the most significant motivational factors of high school students that arise in them before choosing a higher education institution. In conducting our research, we examined the higher education system and sought answers to the role that modern education systems play in the selection of a higher education institution. Based on these, we conducted primary research in Hungary in order to get a comprehensive picture of the key factors for students that play a role in the selection of an institution. As a first step, a research plan was developed that included the research methodology, as well as hypotheses and assumptions related to the topic. In the first part of our study, modern education systems and the higher education system were presented with the help of domestic and international literature. For the practical part, our primary data collection took the form of a direct mail questionnaire, with the help of which we examined secondary school institutions in Hungary. In sending out our questionnaire, we asked secondary school instructors to please ask only graduate students to complete the questionnaire. The construction was done using Survio and Google Form Builder software. The authors believed that they could only and comprehensively provide a comprehensive picture to the reader by specifically addressing the individuals personally affected by this topic. The feedback responses were coded using Microsoft Excel, and then we applied the SPSS program to examine our formulated hypotheses. In the first part of our method of quantitative analysis, we were interested in which category graduating students belong to based on their grades. In this, the research subjects had the opportunity to mark one of the following answer options: excellent (5), good (4), average (3), sufficient (2). Then we looked for the answer to whether they would like to continue their studies at a higher education institution. In our next question, we placed great emphasis on which factors influence the most when choosing a higher education institution if they want to continue their studies. Responses included, for example, the standard of a 
university, the professionalism of the lecturers, the equipment of the university, the level of language teaching, scholarship opportunities, mobility programs, or even the proximity of the university to their place of residence. Students had the opportunity to answer the question on a Likert scale from one to five.

After reviewing the theoretical part of our analysis, the next important part of our research was the presentation of the results of our study. With the help of the hypothesis formulated in connection with the topic, we wanted to research what motivational factors are present among Hungarian secondary school students when choosing a higher education institution. Two research questions were formulated as assumptions:

1. In selecting a higher education institution, the students who perform best consider the reputation and quality of the institution as an important factor.

2. When selecting a higher education institution, it is irrelevant for the students who perform best to be close to their place of residence.

We considered it an important factor to present our results to the reader in an appropriate way after answering the central question. As a result, we illustrate the results of the research using various graphic solutions. Based on the order of importance of the motivational factors encountered in graduating high school students, the first step was to create a preference order. In addition, we aimed to make a step-by-step representation of the elements of the pyramid we created on which higher education institutions have an influential power. A total of 311 high school students joined our primary data collection. When filling in the questionnaires, we placed great emphasis on the recipients, is the leaders and teachers of secondary schools and grammar schools, asking for the help of students who want to study further, and strengthening the camp of students with excellent or good grades. Taking these factors into account, 270 of the 311 responses received were evaluable for us.

\section{Results}

The subjects of the research were asked about the destination country in case they wanted to study abroad. Students who would prefer to study abroad prefer English higher education institutions (20.7\%). The second most popular country is the United States $(14.7 \%)$, followed by Austria (12\%). They believe that when choosing a higher education institution, the most important thing is that they are taught by qualified instructors (4.39) (preferably masters in the field) and that they can successfully enter the labor market and obtain a wellpaying job after graduation. (4.40). After learning which factors, how important are considered by the best performing students, we selected those on which higher education institutions have an influential power. Universities and colleges cannot influence the institution's proximity to the student's place of residence, the fact that the student's acquaintances visit the university or college, nor the fact that the education is free for the student or that the student gets a well-paying job. just because he graduated there. A stepwise representation of the eight selected elements was made, as illustrated in Figure 1. Using the knowledge acquired during the preparation of the study for each degree, we placed the factors outlined above in a logical order. 


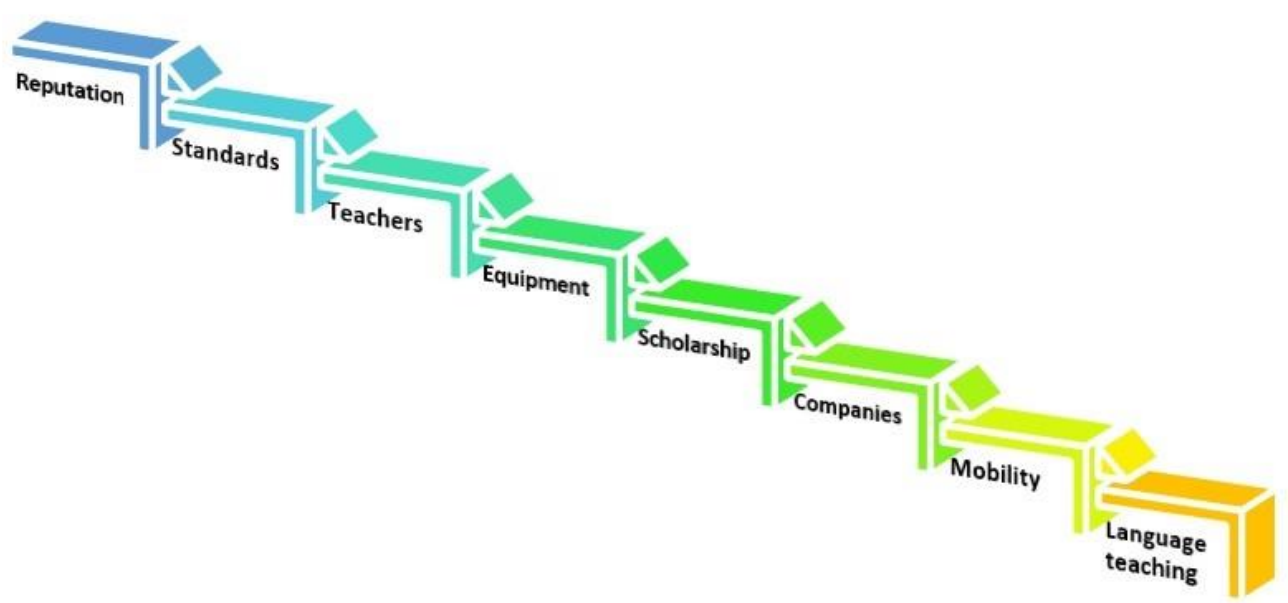

Figure 1. Stepwise representation in terms of increasing the reputation of Hungarian higher education institutions

The higher we go up the stairs, the harder it is to reach the factor at that level in a higher education institution. We have placed the level of language teaching at the lowest level, as to achieve this it is necessary for the institution to launch language courses. Mobility requires various partner institutions to which students can even travel to study under the Erasmus+ program. By acquiring new culture, new views, new knowledge, they broaden their horizons. In addition to liaising with other higher education institutions, it is important that the institution also has relationships with various companies. This can be relevant for dual training, internships, but also for future job search. On the further steps, elements were placed which require a larger amount of material to provide. This also includes scholarships covered by own resources, which not all institutions can afford, but which, according to future students, also play an important role in the selection of a higher education institution.

The equipment of the institution also depends on this factor, as students feel much more comfortable in a beautiful, modern environment where the technical conditions they require are given, the classrooms are equipped and the library offers a wide range of specialist literature. If we go one step higher, we will meet with teachers from higher education institutions. Capital also plays a role in this case, as instructors need to be provided with a competitive salary. If the language teaching is adequate, there are mobility opportunities, the institution maintains good relations with various companies, there are opportunities to receive scholarships, the institution is well equipped and the teachers have a great deal of professional knowledge, which leads to an increase in the quality of the higher education institution. And if all this is fulfilled, the rise in the standard will attract the growth of the reputation and the recognition of the institution. This is at the top of our stepwise representation.

The first assumption can be said to be false as it has not been fully substantiated. Although the best performing students say that the quality of a higher education institution is one of the most important factors when choosing a higher education institution, reputation has only found a place in the lower part of our pyramid. The other assumption is that when 
choosing an institution, it is not relevant that it is close to the student's place of residence. This suggestion has been confirmed.

\section{Discussion}

In the first part of our study, we provided an insight into the functioning of higher education systems. Then we examined the institutional factors that have a motivating effect on high school graduates to choose that university for their further study. As a next step, with the help of domestic and international literature, we grouped the Hungarian students in terms of their further learning attitude. In addition, we placed great emphasis on reviewing each institutional choice model, and the options which available to each higher education institution to encourage prospective students to make good decisions. As a last step, we sought an answer to the question of what are the motivational factors for foreign students, based on which they made the decision that they would like to continue their studies in Hungary. In the next part of our study, we present to the reader the aim and the methodology of the research. Our quantitative questionnaire research included two central research question on which we based our analysis. We were interested the opinion of Hungarian high school graduates about the factors that matter the most to them before choosing a higher education institution. In the course of our research results, we have created a stepwise representation that helps higher education institutions to increase their reputation.

\section{Conclusions}

As a first step in our analysis, we selected the factors that are influenced by higher education institutions in order to achieve a preference for prospective students. Although institutions are not able to influence the distance of between the student's home and the institution, whether the student's acquaintances are the students of the university, nor whether the education is free for that student or whether he or she gets a good job after graduating. As a result, in order to be successful in marketing and communication, they need to focus the activities they are able to influence. Based on our results, we have prepared a stepwise representation in order to provide a comprehensive picture for higher education institutions about which factors need to be strengthened in the future. It is important to note that in order to be successful, universities should only move to the next level if the ones before it have been completed. In today's knowledge-society, it is paramount importance that institutions launch their own language courses, provide Erasmus+ programs, and maintain good relation with companies. Furthermore, it is not possible to go without a word about the various scholarship opportunities and the professionalism of the instructors. If institutions take these factors into account, they can achieve greater success in the future. The main limitation of our research was caused by the pandemic. As a result, it was more difficult to reach graduating high school students. Because of the pandemic, we reached them online with questionnaires sent to schools, however, as this was an indirect method, it was difficult to reach as many students as possible. If we had had the opportunity to visit the schools in person, it would probably have resulted more completions. In the future, we would like to 
extend our research to more countries, and we also would like to expand the literature of the topic.

Acknowledgments: The scientific article is a partial output from the KEGA project 005UJS-4/2019 entitled "Streamlining Managerial Sills of the generations $Z$ and $Y$ by gamification on the context of linking science and practice", which is solved at the Faculty of Economics and Informatics of the J. Selye University in Komárno.

\section{References}

Aithal, P. S., \& Aithal, S. (2016). Impact of on-line education on higher education system. International Journal of Engineering Research and Modern Education, 1(1), 225-235. https://doi.org/10.5281/zenodo.62029

Belas, J., Gavurova, B., Korony, S., \& Cepel, M. (2019). Attitude of University Students toward entrepreneurship environment and toward entrepreneurship propensity in Czech Republic and Slovak Republic. International Comparison. Economic Research - Ekonomska Istrazivanja, 32(1), 2500-2514. https://doi.org/10.1080/1331677X.2019.1615972

Csuka, G., \& Banász, Z. (2014). Lehetőségek és döntések. Educatio, 23(4), 616-631.

European Commission. (2009). Higher education in Europe 2009: Developments in the Bologna Process. Education, Audiovisual and Culture Executive Agency.

European Comission. (2017). Higher education in Europe. https://ec.europa.eu/education/study-ineurope/planning-studies/european-higher-education_en

Eurydice. (2020, January 20). Magyarország: Az oktatási rendszer felépítése. European Commission. https://eacea.ec.europa.eu/national-policies/eurydice/magyarorsz\%C3\%A1g/organisation-educationsystem-and-its-structure_hu

Halász, G. (2001). Az oktatási rendszer. Müszaki Könyvkiadó.

Hofmeister, T. Á. (2006). Fogyasztói magatartás. Aula Kiadó.

Hungarian Central Statistical Office. (2020). Népesség, népmozgalom (1900-). https://www.ksh.hu/docs/hun/xstadat/xstadat_hosszu/h_wdsd001a.html

Jackson, S. J. (2015). Does an early college readiness signal discourage college application and enrollment? Journal of Research on Educational Effectiveness, 8(3), 380-399. https://doi.org/10.1080/19345747.2014.984885

Kéri, A. (2015). A magyar felsőoktatásban tanuló külföldi hallgatók motivációjának vizsgálata. TDK mühelytanulmányok: „első szárnypróbálgatások”, (15), 21-38.

Kuráth, G. (2007). A beiskolázási marketing szerepe a hazai felsőoktatási intézmények vonzerôfejlesztésében. Pécsi Tudományegyetem Közgazdaságtudományi Kar. Regionális Politika és Gazdaságtan Doktori Iskola.

Meijs, C., Neroni, J., Gijselaers, J. M. H., Leontjevas, R., Kirschner, A. P., \& Groot, D. R. (2019). Motivated strategies for learning questionnaire part B revisited: New subscales for an adult distance education setting. The Internet and Higher Education, 40, 10-11. https://doi.org/10.1016/j.iheduc.2018.09.003

Portfolio. (2020). Csaknem 110 ezer diplomát állitottak ki nyelvvizsgamentesen Magyarországon. https://www.portfolio.hu/gazdasag/20200910/csaknem-110-ezer-diplomat-allitottak-kinyelvvizsgamentesen-magyarorszagon-448242

Rámháp, S. (2017). Felsőoktatási továbbtanulási motivációk Magyarországon. A változó ifjúság és a piacosodó felsőoktatás tükrében. Széchenyi István Egyetem. Regionális- és Gazdaságtudományi Doktori Iskola. 